\title{
Evaluation of lysozyme, complement C3, and total protein in different developmental stages of Caspian kutum (Rutilus frisii kutum K.)
}

\author{
Razieh Abdollahi, Behrooz Heidari, Mahmoudreza Aghamaali
}

Received - 22 October 2015/Accepted - 01 March 2016. Published online: 31 March 2016; (Inland Fisheries Institute in Olsztyn, Poland Citation: Abdollahi R., Heidari B., Aghamaali M. 2016 - Evaluation of lysozyme, complement C3, and total protein in different developmental stages of Caspian kutum (Rutilus frisii kutum K.) - Arch. Pol. Fish. 24: 15-22

\begin{abstract}
In this study, non-specific immune parameters in fertilized eggs, eyed embryos, larvae 10, 25, 50, 60, and 70 days post hatch (DPH), and female broodstock of Caspian kutum, Rutilus frisii kutum (Kamensky), were evaluated. The lysozyme activity, complement C3, and total protein levels were measured with the turbidimetric, immunoturbidimetric, and Bradford methods, respectively. The results showed that lysozyme levels decreased from levels noted in the fertilized eggs until the larvae were 10 days old. Subsequently, significant increases in lysozyme levels were observed until 70 DPH. An increasing trend of complement component C3 was noted from the levels in fertilized eggs to $10 \mathrm{DPH}$, following which it decreased significantly. Total protein levels differed significantly in early developmental stages of Caspian kutum. The higher values of complement component C3 than of lysozyme in the early life stages could be indicative of the former's more fundamental role.
\end{abstract}

Keywords: Caspian kutum, lysozyme, C3, development

R. Abdollahi, B. Heidari [" $\Xi^{\circ}$, M. Aghamaali

Department of Biology, Faculty of Science, University of Guilan,

Rasht, Iran

B. Heidari

Caspian Sea Basin Research Center, Department of Marine Sciences, University of Guilan, Rasht, Iran

email: Bheidari@guilan.ac.ir, Behrooz1072@yahoo.com

\section{Introduction}

The eggs of most fishes are released and fertilized externally, which means that the resulting embryos and larvae are exposed to an aquatic environment full of potential pathogens (Zapata et al. 2006). At hatching, the immune system of fish larvae is still developing and lacks the functionality found in adults (Ellis 1999, Zapata et al. 1990). As a result, it is crucial for these early developmental stages to have protective immune mechanisms. They can be protected by both innate and adaptive immune substances transferred from the female broodstock to the eggs during vitellogenesis (Magnadóttir et al. 2005). Innate immune factors such as lysozyme (Yousif et al. 1991, 1994) and complement component C3 (Huttenhuis et al. 2006, Løvoll et al. 2007, Wang et al. 2008) are considered to play substantial roles in larval survival (Mulero et al. 2008, Chettri et al. 2012).

Lysozyme is an important defense molecule of the innate immune system mediating protection against microbial invasion. Lysozyme, also referred to as $\mathrm{N}$-acetylmuramide glycanohydrolase or muramidase, is a well-studied bacteriolytic enzyme identified in a wide range of organisms including fish (Alexander and Ingram 1992). In the larval stage, lysozyme is one of the most important proteins involved in non-

(c) Copyright by Stanisław Sakowicz Inland Fisheries Institute in Olsztyn.

C 2016 Author(s). This is an open access article licensed under the Creative Commons Attribution-NonCommercial-NoDerivs License

(http://creativecommons.org/licenses/by-nc-nd/3.0/). 
specific defenses at a very early stage (Takemura 1996) when the specific immunological response is not yet developed. Lysozyme has been detected in oocytes, fertilized eggs, and larval stages of several fish species (Kudo 1991, 1992, Brown et al. 1997).

The complement system is an important element of both the innate and adaptive immune systems (Lange et al. 2004a, b), and it participates in several defense mechanisms such as the formation of the membrane attack complex, opsonization, and the development of antibodies (Lambris et al. 1993, Mauri et al. 2011). The third complement component (C3) is a key protein of the complement system and a major humoral factor in host defense (Nakao et al. 2004). Complement component C3 is synthesized in the liver and is also expressed in other tissues such as gills, the intestine, and the skin (Engstad et al. 1992, Mauri et al. 2011). Complement component C3 was studied in Atlantic halibut, Hippoglossus hippoglossus (L.) larvae (Hermannsdottir et al. 2009, Lange et al. 2004a) and Atlantic cod, Gadus morhua L. larvae (Lange et al. 2004b), in the eggs and embryos of zebrafish, Danio rerio (Hamilton) (Wang et al. 2009), and in spotted wolffish, Anarhichas minor Olafsen (Ellingsen et al. 2005).

Caspian kutum, Rutilus frisii kutum (Kamensky), is an endemic species distributed in the southern Caspian Sea and the rivers that flow into it (Heidari et al. 2010). This species is one of the most valued fishes on the Iranian Caspian Sea coast (Holčik 1995). Kutum becomes sexually mature at an age of 3-4 years, and the size of mature individuals ranges from 25 to $58 \mathrm{~cm}$ (Bani and Vayghan 2011). The Caspian kutum is a migratory, anadromous fish that spawns on aquatic weeds, gravel and sandy substrates in rivers, and in lagoons from March to April (Gharache et al. 2013). The larvae hatch in 8.5-9 days post-fertilization at $14-16^{\circ} \mathrm{C}$ (Jafari et al. 2010). With the onset of exogenous feeding on the tenth day, the yolk sac is mostly absorbed and all tissues and organs are formed 10 days after hatching (Jafari et al. 2009).

Increasing fish resistance to diseases, especially in the early developmental stages of the Caspian kutum, through the detailed study of the immunity parameters can be helpful in maintaining stock resources. Hence, the aim of the present study was to investigate variations in lysozyme activity and complement component C3 levels in the Caspian kutum from fertilized eggs to larvae (from the age of 10 to 70 days post hatch (DPH)) and in female broodstock.

\section{Material and Methods}

\section{Sampling}

Fertilized eggs (1 hour after fertilization) and eyed embryos (6 days after fertilization) were obtained from Shahid Ansari Farming Center in April and transported alive to the Marine Biology Laboratory at the University of Guilan. After unhealthy fertilized eggs and eyed embryos had been removed, the healthy ones were rinsed three times with sterile phosphate-buffered saline (PBS) at pH 7.2. The eggs were immediately homogenized with PBS (weight1:volume10) for $1 \mathrm{~min}$ and centrifuged at $6000 \mathrm{rpm}$ for $20 \mathrm{~min}$ at $4^{\circ} \mathrm{C}$. The supernatant was pooled, aliquoted, and stored at $-70^{\circ} \mathrm{C}$ until the parameters were analyzed. Caspian kutum larvae $(10,25,50,60$ and $70 \mathrm{DPH})(\mathrm{n}=150$ at each larval stages) were obtained from Shahid Ansari Farming Center during in April, May, June, July, and August, respectively. The samples were fed twice daily with a feeding powder purchased from Isfahan Mokammel Co. (Isfahan, Iran). Whole bodied samples were immediately homogenized with PBS for $1 \mathrm{~min}$, and a protease inhibitor cocktail (Sigma-Aldrich, St. Louis, MO, USA) was added, and then it was centrifuged at $6000 \mathrm{rpm}$ for $20 \mathrm{~min}$ at $4^{\circ} \mathrm{C}$, and finally the supernatant was frozen at $-70^{\circ} \mathrm{C}$ until analysis. The Caspian kutum female broodstock $(n=5)$ was provided by the Shahid Ansari Farming Center in April, and the fish were bled from the caudal vein with a heparinized syringe. After centrifuging, the plasma was frozen until assays of lysozyme and C3.

\section{Lysozyme assay}

The lysozyme activity of the samples (the plasma from the broodstock and the prepared egg and larval 
homogenates) were measured using a method based on the ability of lysozyme to lyse the bacterium Micrococcus lysodeikticus (Ellis 1999). Quantities of $100 \mu \mathrm{l}$ of the samples were mixed with $200 \mu \mathrm{l}$ of a 0.2 $\mathrm{mg} \mathrm{ml}^{-1}$ suspension of $M$. lysodeikticus (Sigma-Aldrich, St. Louis, MO, USA) in a phosphate buffer (pH 6.2, M 0.1). Optical density was read at $450 \mathrm{~nm}$ at $0,15,30$, and $60 \mathrm{~min}$. The lysozyme values are expressed as $\mathrm{U} \mathrm{mg}^{-1}$ total protein.

\section{Complement component C3 assay}

The method of immunoturbidimetry with separated Eastbiopharm ELISA kits (Hangzhou Eastbiopharm CO., LTD., Torrance, USA) was used in the assay for complement component C3 levels. The kit uses a double-antibody sandwich enzyme-linked immunosorbent assay (ELISA) to assay the level of complement component C3 in the samples. Complement component $\mathrm{C} 3$ was added to a monoclonal antibody enzyme well which was pre-coated with a fish complement component C3 monoclonal antibody. This was incubated, and then complement component C3 antibodies labeled with biotin were added and combined with Streptavidin-HRP to form an immune complex. Then the material was incubated and washed again to remove the uncombined enzyme. Then, chromogen solution A, B, was added, and the color of the liquid changed to the blue, and from the effect of sulfuric acid (M 2), the color finally became yellow. The optical density (OD) value was measured with an ELISA reader at $450 \mathrm{~nm}$. The $\mathrm{C} 3$ values are expressed as $\mathrm{mg} \mathrm{ml}^{-1}$.

\section{Total protein assay}

A modification of the Bradford method (Bradford 1976) was used to measure total protein using Coomassie Brilliant blue G-250 as the protein indicator. The optical density was read at $595 \mathrm{~nm}$ for 10 $\mu \mathrm{l}$ aliquots of the diluted homogenate using bovine serum albumin as the standard. The total protein values are expressed as $\mathrm{mg} \mathrm{ml}^{-1}$.

\section{Statistical analysis}

The raw data on the lysozyme and total protein of samples were initially tested assuming normality and homogeneity of variance. In cases in which the assumptions were met, the data were analyzed in the fertilized eggs, eyed embryos, and larvae 10, 25, 50, 60, 70 DPH with one-way analysis of variance (ANOVA) in SPSS (Version 20, IBM). The Duncan post hoc test was used to identify significant differences among the various means at a confidence level of $95 \%$. All experiments were performed in triplicate, and the values were expressed as means \pm SD.

\section{Results}

\section{Lysozyme}

There was a significant difference in lysozyme activities among various developmental stages of Caspian kutum $(\mathrm{P}<0.05)$ (Fig. 1). The lysozyme levels from the fertilized egg to $10 \mathrm{DPH}$ stages decreased $(\mathrm{P}<0.05)$, and after this there was a significant increase in the level until 70 DPH $(\mathrm{P}<0.05)$. There was a significant reduction between the lysozyme of the female broodstock (13.21 $\left.\pm 2.31 \mathrm{U} \mathrm{mg}^{-1}\right)$ and larvae $70 \mathrm{DPH}(\mathrm{P}<0.05)$.

\section{Complement component C3}

A significant difference in complement component C3 levels was observed during various early life stages of Caspian kutum. Complement component C3 levels showed a significant increment from fertilized egg to $10 \mathrm{DPH}(\mathrm{P}<0.05)$, so that the highest value of $\mathrm{C} 3$ was found on day 10 post hatch $(0.673$ \pm 0.02). Then, decreasing levels of C3 were observed until the end of the experimental period $(\mathrm{P}<$ 0.05) (Fig. 2). Compared to $10 \mathrm{DPH}$, there were no significant variations in C3 from larvae 50 to 70 DPH and plasma C3 of the female broodstock (0.4 $\left.\pm 0.02 \mathrm{mg} \mathrm{ml}^{-1}\right)(\mathrm{P}>0.05)$. 


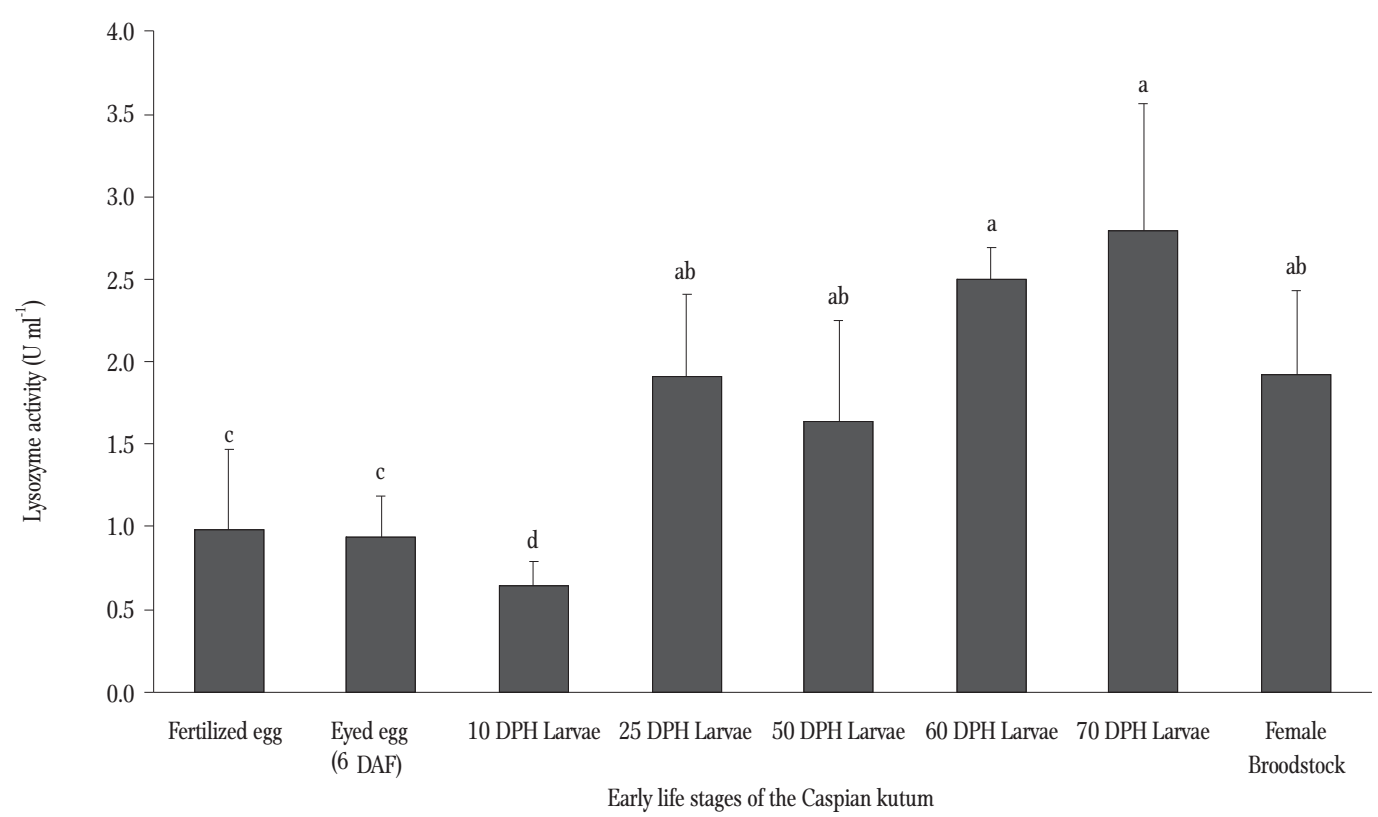

Figure 1. Comparison of lysozyme levels in early life stages (eggs and larvae) of Caspian kutum. Statistical significance determined at P < 0.05 .

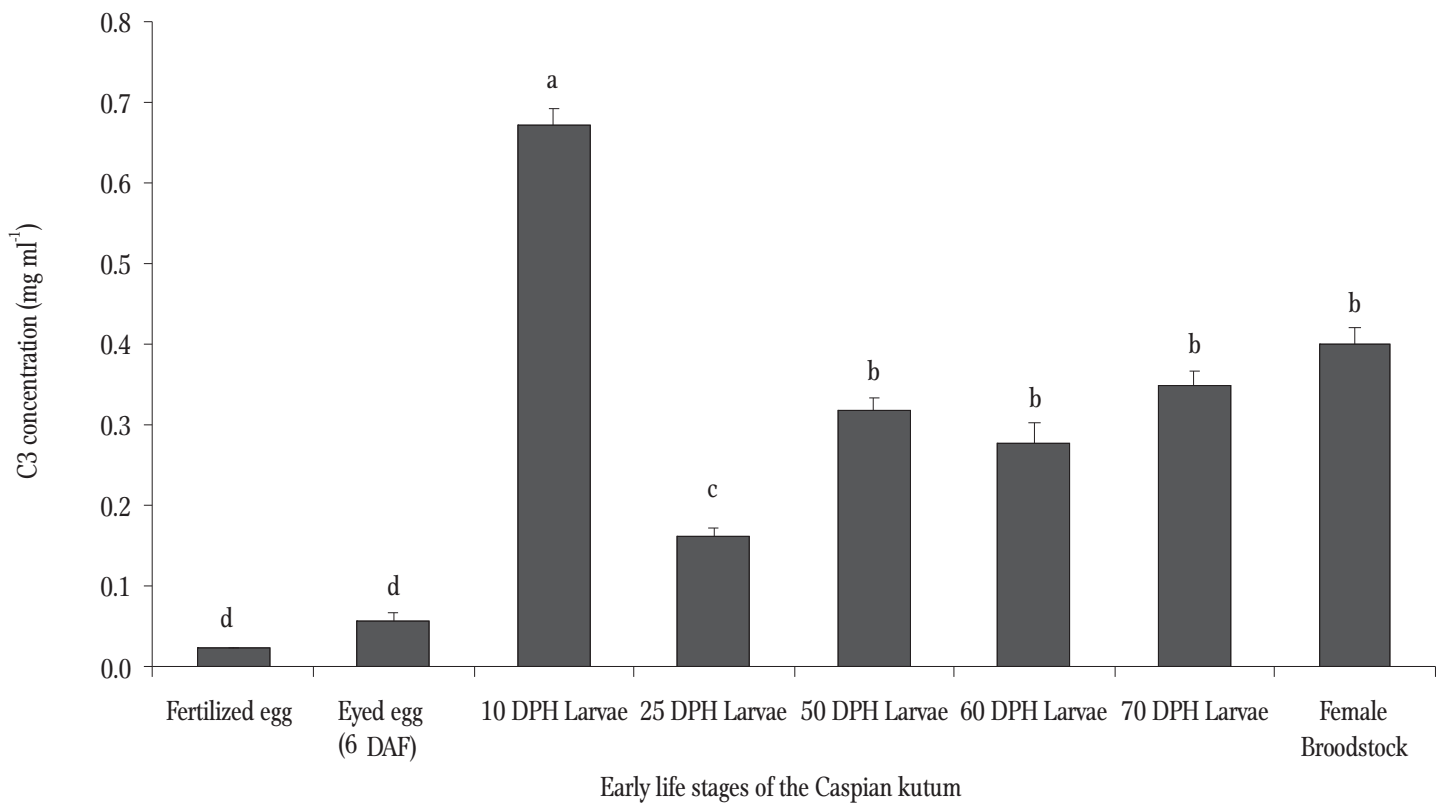

Figure 2. Comparison of complement component C3 levels in early life stages (eggs and larvae) of Caspian kutum. Statistical significance determined at $\mathrm{P}<0.05$.

\section{Total protein}

Significant differences in total protein levels were noted in the early life stages of Caspian kutum $(\mathrm{P}<0.05)$. There was a significant increment in the total protein levels from fertilized egg to larvae $25 \mathrm{DPH}(\mathrm{P}<0.05)$ (Fig. 3). Afterwards, there were significant fluctuations in the total protein levels in larvae after $25 \mathrm{DPH}$ to 70 $\mathrm{DPH}$, so that a remarkable decreasing trend was eventually observed in larvae $60 \mathrm{DPH}(\mathrm{P}<0.05)$. A significant reduction in the plasma total protein in female broodstock (54.79 $\pm 2.31 \mathrm{mg} \mathrm{ml}^{-1}$ ) compared to larval stages of Caspian kutum was observed $(\mathrm{P}<0.05)$. 


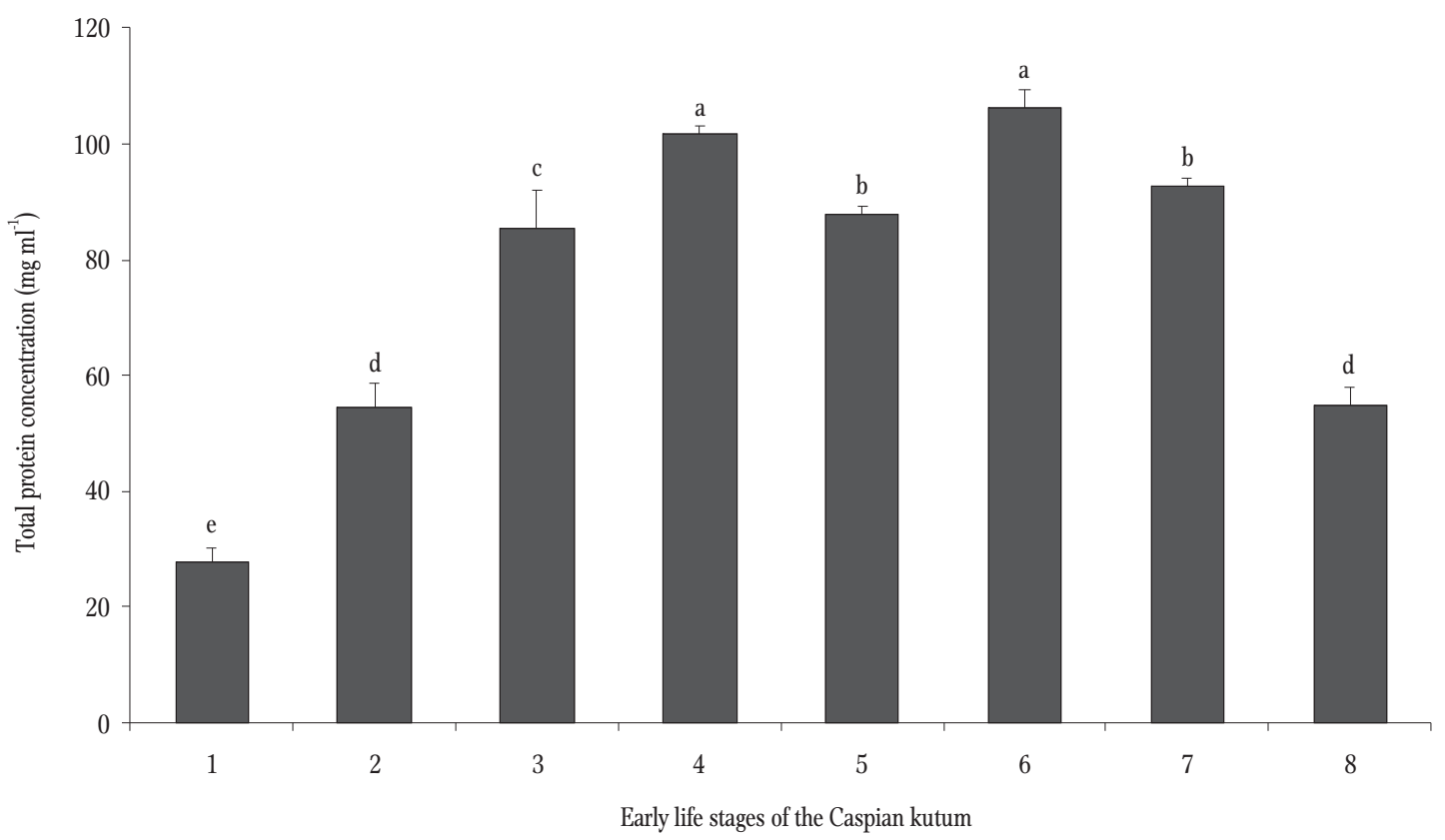

Figure 3. Comparison of total protein in early life stages (eggs and larvae) of Caspian kutum. Statistical significance determined at $\mathrm{P}<0.05$.

\section{Discussion}

Fish larvae must have defensive factors that play anti-infective roles before their own defense mechanisms are fully developed if they are to survive attacks by pathogens. Proteins involved in both the innate and adaptive immune responses of fish, which are transferred maternally, are such factors (Mulero et al. 2007).

Since the immune system of eggs and larvae have not completely developed, they need defensive factors such as lysozyme and complement component C3, both of which are involved in the innate and adaptive immune responses of fish. It is likely that the cooperation of lysozyme and C3 in the defense against pathogens does occur in early developmental stages of fishes (Wang and Zhang 2010).

Lysozyme has been detected in oocytes, fertilized eggs, and larval stages of several fish species, for example, in the eggs of coho salmon, Oncorhynchus kisutch (Walbaum), (Yousif et al. 1991) and other salmonids (Yousif et al. 1994), sea bass, Dicentrarchus labrax (L.), (Cecchini et al. 2000), tilapia, Oreochromis mossambicus (Peters), (Takemura and Takano 1995) and other species.
Lysozyme in eggs has been shown to play a role in the prevention of mother to progeny (vertical) transmission of some bacterial pathogens like Aeromonas salmonicida (Magnadóttir et al. 2005). A study of the lysozyme activity in developmental stages of sea bass showed higher lysozyme activity in newly fertilized eggs than in embryos and larvae $144 \mathrm{~h}$ old (Cecchini et al. 2000). In the present study, the lysozyme activity decreased from fertilized eggs to larvae $10 \mathrm{DPH}$ in Caspian kutum. The high level of lysozyme in fertilized eggs and eyed embryos could indicate the maternal transfer of this enzyme during vitellogenesis. The decreasing trend of lysozyme levels in fertilized eggs, eyed embryos, and larvae $10 \mathrm{DPH}$ larvae could be attributed to yolk absorption, which is complete at 10 DPH (Jafari et al. 2009). Takemura (1993) reported a similar decrease in maternally-derived immunoglobulin proteins in larval stages of tilapia, $O$. mossambicus, as the yolk was absorbed. After day 10 , the lysozyme levels of Caspian kutum showed an increasing level in larvae older than 10 days until day 60 . It seems that the reason behind increased levels of lysozyme after day 10 was the development of various organs and tissues such as the kidney, liver, spleen, alimentary tract, and gills (Jafari et al. 2009), 
which play significant roles in the production of lysozyme.

The presence of C3 has been demonstrated in the eggs and embryos of D. rerio (Wang et al. 2009) and A. minor (Uribe et al. 2011). In H. hippoglossus, C3 was detected in larvae from days 5 to 99 after hatch (Hermannsdottir et al. 2009, Magnadóttir et al. 2005). A growing body of evidence suggests that the C3 complement might play important roles in diverse biological processes ranging from early hematopoiesis to skeletal and vascular development and normal reproduction (Rooney et al. 1993, Andrades et al. 1996, Lange et al. 2004a, b). In addition, earlier findings (Lange et al. 2004a, b) suggest that complement component $\mathrm{C} 3$ could play a role in the generation of cells and tissues in the early developmental stages of this fish.

In Caspian kutum, our results showed a significant increment of complement component C3 from fertilized eggs to larvae $10 \mathrm{DPH}$, so that on day $10 \mathrm{PH}$ the highest levels was observed. The presence of complement component C3 in the eggs and larvae of Caspian kutum could be indicative of its defensive role against pathogens in larval stages. In addition, the high concentration of C3 in larvae compared to that in the eggs and embryos of Caspian kutum is related to the development of the adaptive immune system in fish. With regards to the diverse biological processes of complement component C3, the highest levels of C3 in larvae $10 \mathrm{DPH}$ probably refers to the generation of cells and tissues at this stage of larval development. It is reported that on day 10 after hatch, the organogenesis process of the Caspian kutum larvae is completed and they started exogenous feeding (Jafari et al. 2010). In larvae older than 10 days, complement component C3 decreased, which is likely attributed to the completion of tissue generation.

Apart from lysozyme and C3, there are the other antimicrobial proteins in the non-specific immune system. Accordingly, in the present study, the total protein of the early developmental stages of Caspian kutum was measured. It was observed that total protein increased significantly with increasing age in the embryonic and larval stages of Caspian kutum. In fertilized eggs and eyed eggs, total protein levels could come from yolk proteins that are transferred from the mother. After these stages, the yolk sac was absorbed, and the larvae began exogenous feeding. It seems that an increment of the total protein level in the larvae $10 \mathrm{DPH}$ and later larval stages is related to the development of the digestive organs and immune competence including enzymes and the other immune proteins.

In conclusion, the lowest and highest values of the lysozyme and complement component C3 were recorded in larvae $10 \mathrm{DPH}$, which it the moment of the transitional period between endogenous and exogenous feeding in Caspian kutum. Attention to this larval stage could play a key role in the more efficient culture of Caspian kutum fry.

Author contributions. B.H. designed the experiment and methods; R.A. and M.A. performed the experiment procedures and analyzed the data; R.A. wrote and B.H. corrected the manuscript.

\section{References}

Alexander J.B., Ingram G.A. 1992 - Noncellular nonspecific defence mechanisms of fish - Ann. Rev. Fish. Dis. 2: 249-279.

Andrades J.A., Nimini M.E., Becerra J., Eisenstein R., Davis M., Sorgente N. 1996 - Complement proteins are present in developing endochondral bone and may mediate cartilage cell death and vascularization - Exp. Cell. Res. 227: 208-213.

Bani A., Vayghan H.A. 2011 - Temporal variations in haematological and biochemical indices of the Caspian kutum, Rutilus frisii kutum - Ichthyol. Res. 58: 126-133.

Bradford M.M. 1976 - A rapid and sensitive method for the quantitation of microgram quantities of protein utilizing the principle of protein-dye binding - Anal. Biochem. 72: 248-254.

Brown L.L., Cox W.T., Levine R.P. 1997 - Evidence that the causal agent of bacterial cold water disease Flavobacterium psychrophilum is transmitted within salmonid eggs - Dis. Aquat. Org. 29: 213-218.

Cecchini S., Terova G., Caricato G., Saroglia M. 2000 Lysosome activity in embryos and larvae of sea bass (Dicentrarchus labrax L.), spawned by broodstocks fed with vitamin C enriched diets - Bull. Eur. Assoc. Fish. Pathol. 20: 120-124. 
Chettri J.K., Raida M.K., Kania P.W., Buchmann K. 2012 Differential immune response of rainbow trout (Oncorhynchus mykiss) at early developmental stages (larvae and fry) against the bacterial pathogen Yersinia ruckeri - Dev. Comp. Immunol. 36: 463-474.

Ellingsen T., Strand C., Monsen E., Břgwald J., Dalmo R.A. 2005 - The ontogeny of complement component C3 in the spotted wolfish (Anarhichas minor Olafsen) - Fish. Shellfish Immunol. 18: 351-358.

Ellis A.E. 1999 - Immunity to bacteria in fish - Fish. Shellfish Immunol. 9: 291-308.

Engstad R.E., Robertsen B., Frivold E. 1992 - Yeast glucan induces increase in lysozyme and complement-mediated haemolytic activity in Atlantic salmon blood - Fish. Shellfish Immunol. 2:287-297.

Gharache M.H., Paighambary S.Y., Golpour A. 2013 - Hematological and biochemical indices of kutum Rutilus frisii kutum, associated with capture methods - Comp. Clin. Path. 4: 979-982.

Heidari B., Shabanipour N., Savari A., Yavari V., Hosseini N. 2010 - The oocyte development of Kutum, Rutilus frisii kutum, Kamensky with special emphasis on the zona radiata structure - Anim. Reprod. 6: 465-472.

Hermannsdottir R., Johannsdottir J., Smaradottir H., Sigurgisladottir S., Gudmundsdottir B.K., Bjornsdottir R. 2009 - Analysis of effects induced by a pollock protein hydrolysate on early development, innate immunity and the bacterial community structure of first feeding of Atlantic halibut (Hippoglossus hippoglossus L.) larvae Fish. Shellfish Immunol. 27: 595-602.

Holčik J. 1995 - New data on the ecology of kutum, Rutilus frisii (Nordmann, 1840) from the Caspian Sea - Ecol. Freshw. Fish. 4: 175-179.

Huttenhuis H.B.T., Grou C.P.O., Taverne-Thiele A.J., Taverne N., Rombout J.H.W.M. 2006 - Carp (Cyprinus carpio L.) innate immune factors are present before hatching - Fish. Shellfish Immunol. 20: 586-596.

Jafari M., Kamarudin M.S., Saad C.R., Arshad A., Oryan S., Bahmani M. 2009 - Development of morphology in hatchery-reared Rutilus frisii kutum larvae - Eur. J. Sci. Res. 38: 296-305.

Jafari M., Kamarudin M.S., Saad C.R., Arshad A., Oryan S., Guilani M.H.T. 2010 -Embryonic Development of Caspian kutum, Rutilus frisii kutum - J. World. Aquacult. Soc. 41: 378-390.

Kudo S. 1991 - Further investigation on enzyme activities and antifungal action of fertilization envelope extract from fish eggs - Zool. Sci. 8: 1079.

Kudo S. 1992 - Enzymatic basis for protection of fish embryos by the fertilization envelope - Experientia, 48: 277-281.

Lambris J., Lao Z., Pang J., Alsenz J. 1993 - Third component of trout complement, cDNA cloning and conservation of functional sites - J. Immunol. 151: 6123-6134.
Lange S., Bambir S., Dodds A.W., Magnadóttir B. 2004a - An immunohistochemical study on complement component C3 in juvenile Atlantic halibut (Hippoglossus hippoglossus L.) - Dev. Comp. Immunol. 28: 593-601.

Lange S., Bambir S., Dodds A.W., Magnadóttir B. 2004b The ontogeny of complement component C3 in Atlantic cod (Gadus morhua L.)-an immunohistochemical study - Fish. Shellfish Immunol. 16: 359-367.

Løvoll M., Johnsen H., Boshra H., Bøgwald J., Sunyer J.O., Dalmo R.A. 2007 - The ontogeny and extrahepatic expression of complement factor C3 in Atlantic salmon (Salmo salar) - Fish. Shellfish Immunol. 23: 542-552.

Magnadóttir B., Lange S., Gudmundsdottir S., Bøgwald J., Dalmo R.A. 2005 - Ontogeny of humoral immune parameters in fish - Fish. Shellfish Immunol. 19: 429-439.

Mauri I., Romero A., Acerete L., MacKenzie S., Roher N., Callol A., Cano A., Alvarez M.C., Tort L. 2011 - Changes in complement responses in Gilthead seabream (Sparus aurata) and European seabass (Dicentrarchus labrax) under crowding stress, plus viral and bacterial challenges - Fish. Shellfish Immunol. 30: 182-188.

Mulero I., García-Ayala A., Meseguer J., Mulero V. 2007 Maternal transfer of immunity and ontogeny of autologous immunocompetence of fish: A minireview Aquaculture, 268: 244-250.

Mulero I., Sepulcre M.P., Fuentes I., García-Alcazar A., Meseguer J., García-Ayala A., Mulero V. 2008 - Vaccination of larvae of the bony fish gilthead seabream reveals a lack of correlation between lymphocyte development and adaptive immunocompetence - Mol. Immunol. 45: 2981-2989.

Nakao M., Miura C., Itoh S., Nakahara M., Okumura K., Mutsuro J., Yano T. 2004 - A complement C3 fragment equivalent to mammalian C3d from the common carp (Cyprinus carpio): generation in serum after activation of the alternative pathway and detection of its receptor on the lymphocyte surface - Fish. Shellfish Immunol. 16: 139-149.

Rooney I.A., Oglesby T.J., Atkinson J.P. 1993 - Complement in human reproduction: Activation and control Immunol. Res. 12: 276-294.

Takemura A. 1993 - Changes in an immunoglobulin M (IgM)-like protein during larval stages in tilapia, Oreochromis mossambicus - Aquaculture, 115: 233-241.

Takemura A. 1996 - Immunohistochemical localization of lysozyme in the prelarvae of tilapia, Oreochromis mossambicus - Fish. Shellfish Immunol. 6:75-77.

Takemura A., Takano K. 1995 - Lysozyme in the ovary of tilapia (Oreochromis mossambicus): its purification and some biological properties - Fish. Physiol. Biochem. 14: 415-442. 
Uribe C., Folch H., Enriquez R., Moran G. 2011 - Innate and adaptive immunity in teleost fish: a review - Vet. Med. 56: 486-503.

Wang Z.P., Zhang S.C., Wang G.F., An Y. 2008 - Complement activity in the egg cytosol of zebrafish Danio rerio: evidence for the defense role of maternal complement components - Plos One, 3: e1463.

Wang Z., Zhang S., Tong Z., Li L., Wang G. 2009 - Maternal transfer and protective role of the alternative complement components in zebrafish Danio rerio - Plos One, 4: e4498.

Wang Z., Zhang S. 2010 - The role of lysozyme and complement in the antibacterial activity of zebrafish (Danio rerio) egg cytosol - Fish. Shellfish Immunol. 29: 773-777.

Yousif A., Albright L., Evelyn T. 1991 - Occurrence of lysozyme in the eggs of coho salmon Oncorhynchus kisutch - Dis. Aquat. Organ. 10: 45-49.

Yousif A., Albright L., Evelyn T. 1994 - In vitro evidence for the antibacterial role of lysozyme in salmonid eggs - Dis. Aquat. Organ. 19: 15-19.

Zapata A.G., Torroba M., Varas A., Jimenez A. 1990 - Immunity in fish larvae - Dev. Biol. Stand. 90: 22-32.

Zapata A., Diez B., Cejalvo T., Gutiérrez-de Frías C., Cortés A. 2006 - Ontogeny of the immune system of fish - Fish. Shellfish Immunol. 20: 126-136. 